\title{
Is it possible that the pathogenesis of osteoarthritis could start with subchondral trabecular bone loss like osteoporosis?
}

\author{
Osteoartrit patogenezi osteoporoza benzer şekilde subkondral trabeküler \\ kemik kaybı ile başlıyor olabilir mi?
}

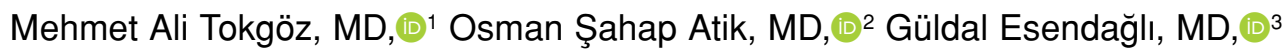 \\ Betül Ögüt, MD, (103 Hasan Hüseyin Bozkurt, MD (D) 1 \\ 'Department of Orthopedics and Traumatology, Medicine Faculty of Gazi University, Ankara, Turkey \\ ${ }^{2}$ Professor of Orthopedic Surgery, Turkish Joint Diseases Foundation, Ankara, Turkey \\ ${ }^{3}$ Department of Pathology, Medicine Faculty of Gazi University, Ankara, Turkey
}

\begin{abstract}
Objectives: This study aims to investigate the role of subchondral trabecular bone thickness in the mechanism of knee osteoarthritis and the correlation of osteoarthritis and osteoporosis pathogenesis.

Patients and methods: The study included 62 patients (9 males, 53 females; mean age 66.7 years; range, 50 to 84 years) with osteoarthritis. All radiographs were evaluated according to Kellgren and Lawrence classification. The bone mineral density of the patients was measured and bone samples were collected from all patients included in the study during the surgical procedure and investigated pathologically.

Results: Osteoarthritis grade and trabecular bone thickness were correlated with each other. Trabecular thickness rate was higher in patients with severe osteoarthritis, whereas trabecular thickness rate was statistically significantly lower than the mean in patients with mild osteoarthritis $(\mathrm{p}=0.045)$.

Conclusion: Trabecular thickness rate was significantly lower in the mild grade of osteoarthritis compared to the severe grade. As the level of osteoarthritis increased, the number of patients with osteoporosis decreased.
\end{abstract}

Keywords: Bone mineral densitometry; osteoarthritis; osteoporosis; subchondral bone loss; trabecular thickness.

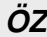

Amaç: $\mathrm{Bu}$ çalışmada, diz osteoartriti mekanizmasında subkondral trabeküler kemik kalınlığının rolü ve osteoartrit ile osteoporoz patogenezinin ilişkisi araştırıldı.

Hastalar ve yöntemler: Çalışmaya osteoartritli 62 hasta (9 erkek, 53 kadın; ort. yaş 66.7 yıl; dağılım, 50-84 yıl) dahil edildi. Tüm radyografiler Kellgren ve Lawrence sınıflamasına göre değerlendirildi. Hastaların kemik mineral yoğunluğu ölçüldü ve cerrahi işlem sırasında çalışmaya dahil edilen tüm hastaların kemik örnekleri toplandı ve patolojik olarak incelendi.

Bulgular: Osteoartrit evresi ve trabeküler kemik kalınlığı birbiriyle ilişkiliydi. Şiddetli osteoartritli hastalarda trabeküler kalınlık oranı daha yüksek iken hafif osteoartritli hastalarda trabeküler kalınlık oranı ortalamadan istatistiksel olarak anlamlı derecede düşük idi $(\mathrm{p}=0.045)$.

Sonuç: Trabeküler kalınlık oranı osteoartritin hafif evresinde şiddetli evreye kıyasla anlamlı derecede daha düşük idi. Osteoartrit düzeyi arttıkça osteoporozlu hasta sayısı azald1.

Anahtar sözcükler: Kemik mineral dansitometrisi; osteoartrit; osteoporoz; subkondral kemik kaybı; trabeküler kalınlık.

Received: September 03, 2018 Accepted: October 06, 2018

Correspondence: Mehmet Ali Tokgöz, MD. Gazi Üniversitesi Tıp Fakültesi Ortopedi ve Travmatoloji Anabilim Dalı, 06500 Beşevler, Ankara, Turkey. Tel: +90 312 - 2025528 e-mail: m.alitokgoz@gmail.com 
Osteoarthritis and osteoporosis are two diseases related to the skeletal system that have high incidence rates. Together with the aging population, incidence rates of both diseases have been rapidly increasing. ${ }^{[1]}$ It has been revealed that the prevalence of arthritis was $4.9 \%$ in the population above 25 years of age, whereas this rate became $16.9 \%$ in the population above 45 years of age..$^{[2]}$ Osteoporosis affects one in four females during the postmenopausal period and $80 \%$ of females above 80 years of age. ${ }^{[3]}$

Although the risk factors, morbidity and mortality rates of osteoarthritis and osteoporosis are different, similar epidemiological groups are affected and changes occur in the bone structure. Many researchers have not found any associations between these two diseases. It has even been reported that bone mineral density is increased in osteoarthritis. ${ }^{[4,5]}$ However, a review of the literature also reveals evidence regarding the opposite point of view. ${ }^{[6]}$ In addition, there are studies which mentioned that the reliability of bone mineral density measurements were doubtful both histologically and clinically. ${ }^{[7,8]}$

The contribution of the subchondral trabecular bone area to the pathology in osteoarthritis has been emphasized by the researchers. The term 'subchondral bone' has been used to refer to both cortical and cancellous part of the bone and mechanical differences that may be critical to understanding the role of subchondral bone in osteoarthritis. Increased bone turnover and porosity (reduced density) were determined in subchondral trabecular bone in osteoarthritis, like osteoporosis. This encouraged us to investigate the subchondral trabecular bone thickness pathologically and compare the mechanisms of both diseases. ${ }^{[9,10]}$

Thus, although there were many studies investigating the correlation between osteoarthritis and osteoporosis, this subject is still controversial. Therefore, in this study, we aimed to investigate the role of subchondral trabecular bone thickness in the mechanism of knee osteoarthritis and the correlation of osteoarthritis and osteoporosis pathogenesis.

\section{PATIENTS AND METHODS}

This study was conducted on patients who were admitted to the Department of Orthopedics and Traumatology of Gazi University Medical Faculty between November 2015 and July 2016 complaining from knee pain, diagnosed as osteoarthritis, and who underwent knee reconstruction.

A total of 379 patients who underwent total knee arthroplasty and diagnosed with osteoporosis and osteoarthritis due to secondary causes were investigated. Patients with abnormalities in the

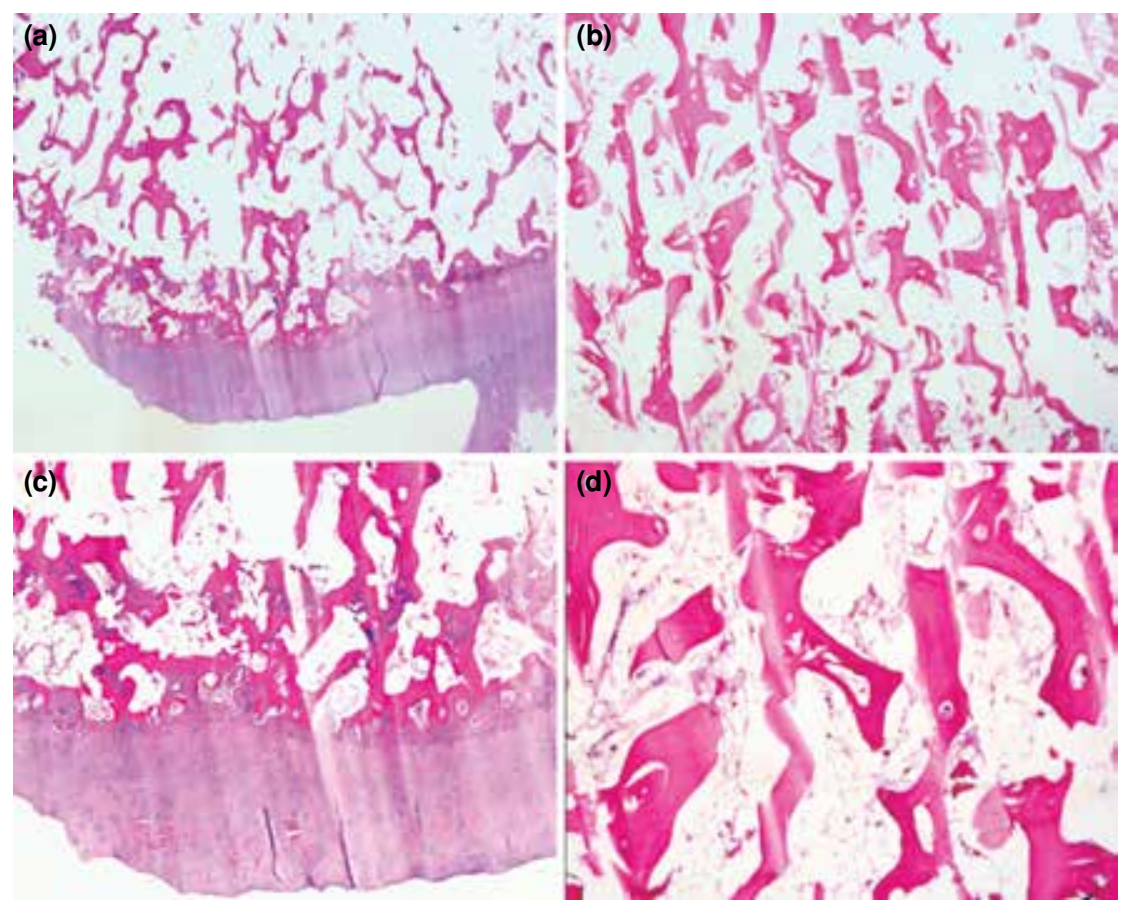

Figure 1. Histopathological examination. Normal bone cortex and trabecular tissue. (a, b) $\mathrm{H}-\mathrm{E} \times 125$, (c, d) $\mathrm{H}-\mathrm{E} \times 400$. 
TABLE ।

Groups according to Kellgren and Lawrence classification

\begin{tabular}{lcc}
\hline & $\mathrm{n}$ & $\%$ \\
\hline Grade 1 & 8 & 12.9 \\
Grade 2 & 16 & 25.8 \\
Grade 3 & 18 & 29.0 \\
Grade 4 & 20 & 32.3 \\
Total & 62 & 100.0 \\
\hline
\end{tabular}

levels of serum electrolyte and alkaline phosphatase were excluded. After these exclusion criteria were performed, a total of 62 patients $(9$ males, 53 females; mean age 66.7 years; range, 50 to 84 years) were included in the study.

Age, gender, Body Mass Index, related joint, and laterality of all patients were noted. Anteroposterior and lateral radiographs were performed for all patients. The bone mineral density of the patients was measured and bone samples were collected from all patients included in the study during the surgical procedure and then investigated pathologically.

The direct radiographs of all patients were performed by the same digital radiography system and
TABLE II

Number of patients according to World Health Organization osteoporosis classification

\begin{tabular}{lcc}
\hline & $\mathrm{n}$ & $\%$ \\
\hline Osteoporotic & 18 & 35.3 \\
Osteopenic & 27 & 52.9 \\
Normal & 6 & 11.8 \\
Total & 51 & 100.0 \\
\hline
\end{tabular}

by the same radiology technician. Radiographs were evaluated according to the Kellgren and Lawrence classification. Hologic QDR 4500C Bone Densitometer (Hologic Inc., Bedford, MA, USA) was used for the measurement of bone mineral density. The levels of bone mineral density were evaluated according to the World Health Organization standards and $\mathrm{T}$ scores below -2.5 were accepted as osteoporosis, radiologically.

In pathology laboratory, after two days of formalin fixation, all samples were kept in $10 \%$ formic acid solution for one week. Some of the samples which were not decalcified and softened enough to have cut section via microtome were placed in decalcifying solution for several days and then embedded in paraffin to

TABLE III

Trabecular thicknesses according to osteoarthritis level

\begin{tabular}{|c|c|c|c|}
\hline \multirow[b]{2}{*}{ Kellgren-Lawrence classification } & \multicolumn{2}{|c|}{ Trabecular thickness } & \multirow[b]{2}{*}{ Total } \\
\hline & $<143$ & $>143$ & \\
\hline \multicolumn{4}{|l|}{ Grade 1} \\
\hline $\mathrm{n}$ & 5 & 3 & 8 \\
\hline$\%$ in osteoarthritis subgroup & 62.5 & 37.5 & 100 \\
\hline$\%$ in trabecular thickness subgroup & 15 & 10.3 & 12.9 \\
\hline \multicolumn{4}{|l|}{ Grade 2} \\
\hline $\mathrm{n}$ & 12 & 4 & 16 \\
\hline$\%$ in osteoarthritis subgroup & 75.0 & 25.0 & 100 \\
\hline$\%$ in trabecular thickness subgroup & 36.4 & 13.8 & 25.8 \\
\hline \multicolumn{4}{|l|}{ Grade 3} \\
\hline $\mathrm{n}$ & 5 & 13 & 18 \\
\hline$\%$ in osteoarthritis subgroup & 27.8 & 72.2 & 100 \\
\hline$\%$ in trabecular thickness subgroup & 15.2 & 44.8 & 29.0 \\
\hline \multicolumn{4}{|l|}{ Grade 4} \\
\hline $\mathrm{n}$ & 11 & 9 & 20 \\
\hline$\%$ in osteoarthritis subgroup & 55.0 & 45.0 & 100 \\
\hline$\%$ in trabecular thickness subgroup & 33.3 & 31.0 & 32.3 \\
\hline \multicolumn{4}{|l|}{ Total } \\
\hline $\mathrm{n}$ & 33 & 29 & 62 \\
\hline$\%$ in osteoarthritis subgroup & 53.2 & 46.8 & 100 \\
\hline$\%$ in trabecular thickness subgroup & 100 & 100 & 100 \\
\hline
\end{tabular}




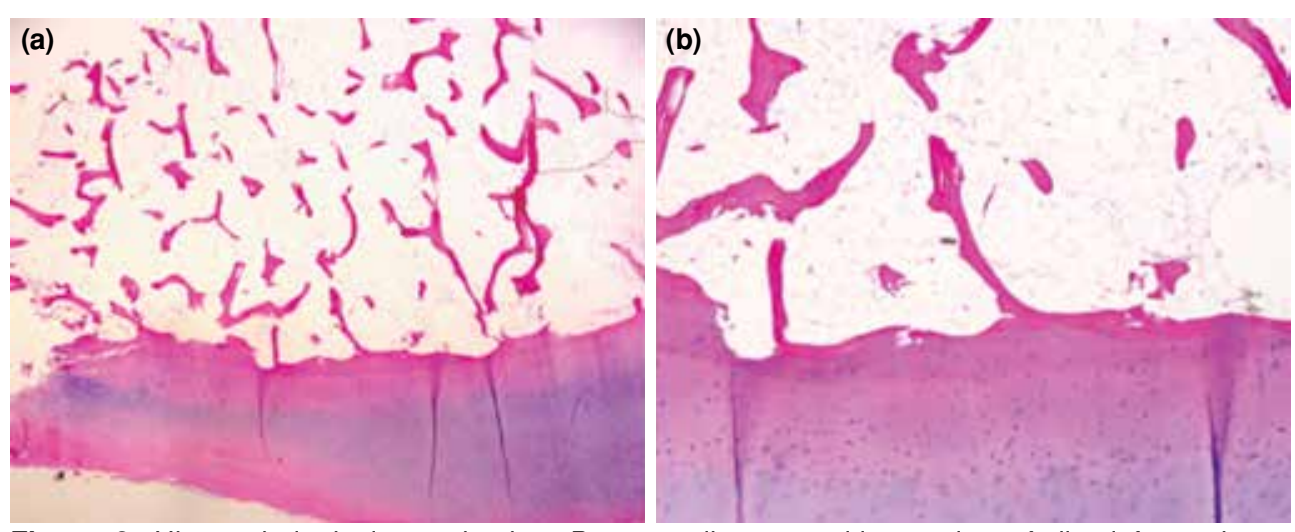

Figure 2. Histopathological examination. Bone cartilage transition region of distal femur in an osteoporotic patient. (a) $\mathrm{H}-\mathrm{E} \times 125$, (b) $\mathrm{H}-\mathrm{E} \times 400$.

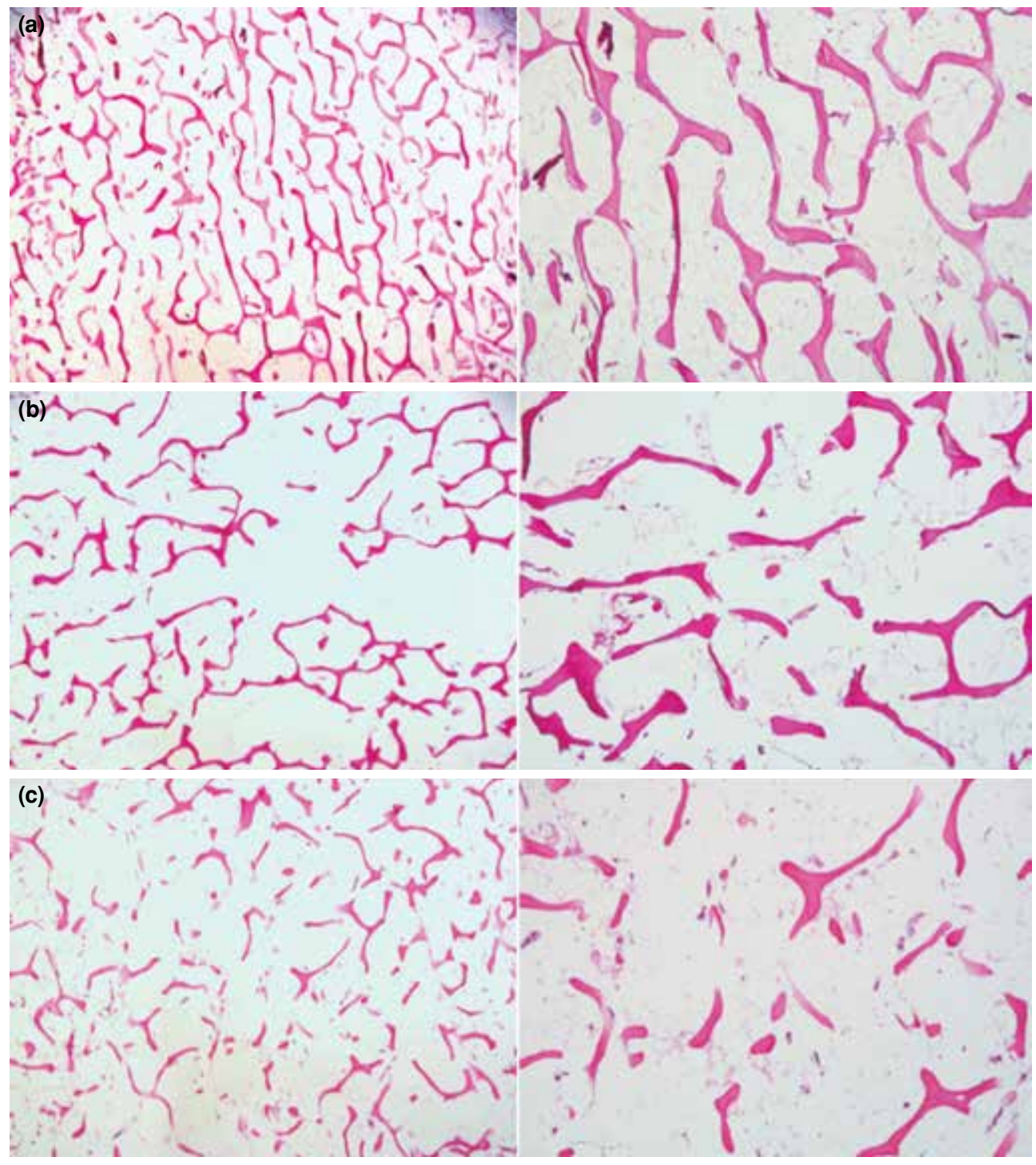

Figure 3. Histopathological examination. Sections from several patients with osteoporosis at various grades showing osteoporotic bone trabeculae and increased adipose tissue in intertrabecular area (a) Mild, (b) Moderate, (c) Severe (Left: H-E×125, Right: H-E×400). 
have tissue blocks. Following preparation of 4-5 $\mu \mathrm{m}$ sections, which include the bone cortex with surface cartilage, tissue sections were stained with routine hematoxylin and eosin stain. Finally, samples were evaluated in terms of osteoporosis and osteoarthritis by two expert pathologists under the Olympus Bx51 microscope (Olympus Optical Co., Ltd., Tokyo, Japan) using a double-blind method. In addition, the thickest and the thinnest bone trabeculae in the samples were measured for each patient (Figure 1).

\section{Statistical analysis}

All statistical analyses were performed using the IBM SPSS version 23.0 program (IBM Corp., Armonk, NY, USA) and a $p$ value $<0.05$ was considered to be statistically significant. The frequency analysis of all data was performed. Chi-square test was used in the comparison of qualitative data and Kruskal-Wallis test was used in the comparison of continuous input.

\section{RESULTS}

The patients were divided into four groups according to the Kellgren and Lawrence classification (Table I) and divided into three groups according to the presence of radiological osteoporosis (Table II). There was no patient with grade 0 according to the Kellgren and Lawrence classification. In addition, patients were divided into two groups in terms of thickness of bone trabeculae to facilitate statistical evaluations.

Trabecular thickness was below the mean in 33 patients and above the mean in 29 patients (Figures 2, 3).

No statistically significant difference could be detected when the osteoarthritis level and radiological osteoporosis were correlated.

A comparison of the osteoarthritis level and trabecular bone thickness showed that these two parameters were correlated with each other. Trabecular thickness rate was higher in patients with severe osteoarthritis, whereas trabecular thickness rate was statistically significantly lower than the mean in patients with mild osteoarthritis $(\mathrm{p}=0.045)$.

\section{DISCUSSION}

In this study, the correlation between osteoporosis and osteoarthritis was investigated. The mean trabecular thickness of the current study was determined to be $0.143 \mathrm{~mm}$, which was obtained via histopathological measurements, and was assented to the cut-off value. This value was also mentioned in similar studies in the literature (Table III). ${ }^{[1,12]}$
When the radiological findings were examined, it was found that $35.3 \%$ of the patients had osteoporosis and $52.9 \%$ of patients had osteopenia. Over the age of 50 years, one in three female and one in five male struggles due to osteoporosis. ${ }^{[3,13]}$ Considering this incidence, it was thought that osteoarthritis patients may also be affected by osteoporosis and this was also demonstrated in the current study.

In the literature, studies conducted on animals have shown that cartilage deterioration was slowed down and the incidence of osteophyte formation was decreased in patients treated with alendronate. ${ }^{[14]}$ In addition, some studies have reported significant changes in pain scores in the short-term when bisphosphonates were started in patients admitted due to osteoarthritis; however, difference in pain was not observed in radiological findings. ${ }^{[6,15,16]}$ On the other hand, that difference was claimed to have disappeared in the medium-term. ${ }^{[17]}$ Although longterm results do not exist, it is interesting to find that patients with these two diseases, whose mechanisms are differently described, have benefited from bisphosphonates in the short-term.

When the mechanism of osteoarthritis development is described in the literature, it is usually focused on subchondral sclerosis and cartilage loss; however, authors who mentioned subchondral bone loss also exist. ${ }^{[18]}$ That effect of bisphosphonates reinforced the idea that pathogenesis of osteoarthritis could start with trabecular bone loss, as it happens in osteoporosis.

In a study conducted by Henrotin et al., ${ }^{[19]}$ it was mentioned that trabeculae of medial side of the knee (deformity side) were thicker than lateral trabeculae in osteoarthritis of knee. In our study, based on the measurements performed in the pathological examination of the subchondral bone samples collected from patients, it was found that the trabecular thickness in the mild grade of osteoarthritis was significantly thinner compared to the severe grade. That information and the other results of our study give rise to the idea that both osteoporosis and osteoarthritis might start to develop at subchondral regions where trabecular thinning takes place. Meanwhile, the positive effect of bisphosphonates in pain scores can be explained in early grade osteoarthritis patients with that hypothesis. ${ }^{[6]}$ Additionally, it was mentioned in a study by Atik et al. ${ }^{[20]}$ that cartilage-bone transition region was structurally irregular, as the microarchitecture and the organic part of the bone were impaired in the osteoarthritic knee. 
Subchondral trabecular loss, which occurs in the whole subchondral region at the early grades of osteoarthritis, causes varus deformity after microfractures occur in weakened trabeculae of bone. With the development of this deformity, the change in the mechanical axis damages the cartilage due to problems in the load transfer and marked joint narrowing is observed. In the severe grades of osteoarthritis, because of the subchondral compression and bone remodeling, sclerosis and trabecular thickening are observed in the side of the deformity although trabeculae of lateral part of the knee still remain thin.

It may also be asserted that this trabecular thinning occurs due to osteoporosis; however, there was no statistically significant difference between the osteoarthritis groups in terms of osteoporosis. Therefore, it was thought that trabecular thinning, which was detected in pathological measurements in early grade osteoarthritis, may be a part of the osteoarthritis pathogenesis by considering the accelerated bone turnover in both diseases. ${ }^{[21]}$

The main limitations of this single-centered study are that the number of male subjects is not sufficient and the sample area is limited to only the distal femural bone. If subsequent multicenter studies are performed with samples from more than one body region with larger and better randomized study groups, the effect of osteoarthritis on bone trabecula may be understood more clearly. Therefore, we hope that this study may provide preliminary information for future studies.

In conclusion, while previous studies indicated that osteoarthritis and osteoporosis are opposite diseases, a new study has been added to the growing number of studies demonstrating that osteoarthritis and osteoporosis can simultaneously exist. Moreover, the importance of loss in subchondral bone mass has been demonstrated radiologically and histopathologically in the pathogenesis of osteoarthritis.

\section{Acknowledgments}

A special debt of gratitude for their invaluable support throughout the development of this study is owed to Sacit TURANLI, Prof., and Muhammet Baybars ATAOĞLU, Ass. Prof. (Gazi University, Ankara)

\section{Declaration of conflicting interests}

The authors declared no conflicts of interest with respect to the authorship and/or publication of this article.

\section{Funding}

The authors received no financial support for the research and/or authorship of this article.

\section{REFERENCES}

1. Bozkurt HH, Atik OŞ, Tokgöz MA. Can distal radius or vertebra fractures due to low-energy trauma be a harbinger of a hip fracture? Eklem Hastalik Cerrahisi 2018;29:100-3.

2. Lawrence RC, Felson DT, Helmick CG, Arnold LM, Choi H, Deyo RA, et al. Estimates of the prevalence of arthritis and other rheumatic conditions in the United States. Part II. Arthritis Rheum 2008;58:26-35.

3. Atik OS, Gunal I, Korkusuz F. Burden of osteoporosis. Clin Orthop Relat Res 2006;443:19-24.

4. Stewart A, Black A, Robins SP, Reid DM. Bone density and bone turnover in patients with osteoarthritis and osteoporosis. J Rheumatol 1999;26:622-6.

5. Burger H, van Daele PL, Odding E, Valkenburg HA, Hofman A, Grobbee DE, et al. Association of radiographically evident osteoarthritis with higher bone mineral density and increased bone loss with age. The Rotterdam Study. Arthritis Rheum 1996;39:81-6.

6. Davis AJ, Smith TO, Hing CB, Sofat N. Are bisphosphonates effective in the treatment of osteoarthritis pain? A meta-analysis and systematic review. PLoS One 2013;8:72714.

7. GülO, Atik OS, ErdoğanD, Göktaş G, Elmas C. Transmission and scanning electron microscopy confirm that bone microstructure is similar in osteopenic and osteoporotic patients. Eklem Hastalik Cerrahisi 2013;24:126-32.

8. Atik OS. Is DXA the gold standard? Eklem Hastalik Cerrahisi 2011;22:63.

9. Burr DB, Gallant MA. Bone remodelling in osteoarthritis. Nat Rev Rheumatol 2012;8:665-73.

10. de Vernejoul MC. Bone remodelling in osteoporosis. Clin Rheumatol 1989;8 Suppl 2:13-5.

11. Ulrich D, van Rietbergen B, Laib A, Rüegsegger P. The ability of three-dimensional structural indices to reflect mechanical aspects of trabecular bone. Bone 1999;25:5560.

12. Koehne T, Vettorazzi E, Küsters N, Lüneburg R, Kahl-Nieke B, Püschel K,et al. Trends in trabecular architecture and bone mineral density distribution in 152 individuals aged 30-90 years. Bone 2014;66:31-8.

13. Body JJ, Bergmann P, Boonen S, Boutsen Y, Bruyere O, Devogelaer JP, et al. Non-pharmacological management of osteoporosis: a consensus of the Belgian Bone Club. Osteoporos Int 2011;22:2769-88.

14. Roux C, Richette P. Impact of treatments for osteoporosis on osteoarthritis progression. Osteoporos Int 2012;23:881-3.

15. Walsh DA, Chapman V. Bisphosphonates for osteoarthritis. Arthritis Res Ther 2011;13:128.

16. Yang W, Zhuo Q, Chai W, Chen J, Sun C, Wang Y. Bisphosphonates for osteoarthritis. Cochrane Database Syst Rev 2013;CD010805.

17. Laslett LL, Kingsbury SR, Hensor EM, Bowes MA, Conaghan PG. Effect of bisphosphonate use in patients with symptomatic and radiographic knee osteoarthritis: data from the Osteoarthritis Initiative. Ann Rheum Dis 2014;73:824-30.

18. Roman-Blas JA, Herrero-Beaumont G. Targeting subchondral bone in osteoporotic osteoarthritis. Arthritis Res Ther 2014;16:494. 
19. Henrotin Y, Pesesse L, Sanchez C. Subchondral bone and osteoarthritis: biological and cellular aspects. Osteoporos Int 2012;23:847-51.

20. Atik OŞ, Erdoğan D, Seymen CM, Bozkurt HH, Kaplanoğlu GT. Is there crosstalk between subchondral bone, cartilage, and meniscus in the pathogenesis of osteoarthritis? Eklem Hastalik Cerrahisi 2016;27:62-7.

21. Atik OS. Is subchondral bone the crucial point for the pathogenesis and the treatment of osteoarthritis? Eklem Hastalik Cerrahisi 2014;25:1. 